\title{
STOCK EXCHANGE REGULATION OF NONMEMBER BROKERS*
}

Although the regulation of securities transactions is primarily the responsibility of the Securities and Exchange Commission, ${ }^{1}$ the supervision of particular transactions in securities listed on a major stock exchange is the responsibility of the particular exchange. ${ }^{2}$ When members of the exchange fail to adhere to "just and equitable principles of trade" in their dealings, the exchange is required by the Securities Exchange Act of 1934 to discipline, suspend or expel such members. ${ }^{3}$ Occasionally, however, an exchange will attempt to regulate the practices of securities dealers who are not members but who rely upon members for information and services. An exchange may, for example, deny certain nonmembers its stock ticker service or enjoin exchange members from having direct wire connections with those nonmembers. In such cases an opportunity to refute the charges underlying the action is sometimes denied. 4 A recent attempt by a national securities exchange to discipline nonmembers raises questions of statutory construction and constitutional limitations.

In Silver $v$. New York Stock Exchange, the plaintiffs ${ }^{6}$ challenged the legality of certain disciplinary action taken against them by the Exchange. In order to conduct business, plaintiffs arranged with a number of securities dealers who were members of the Exchange for the installation of direct wire service, and sought an agreement with the Exchange for installation of stock ticker service. Under the rules of the Exchange, member firms could make such arrangements only with the consent of the Exchange, ${ }^{7}$ and such approval was temporarily granted for both the wire connections and the ticker service in the fall of 1958. On February 12,1959, without prior notice to the plaintiffs,

*Silver v. New York Stock Exch., 196 F. Supp. 209 (S.D.N.Y. 1961).

1. 48 Stat. 898 (1934), 15 U.S.C. § 78s (1958).

2. Shultz, The Securities Market 26-27 (1946).

3. 48 Stat. 885 (1934), 15 U.S.C. \$ $78 f(b)$ (1958).

4. Silver v. New York Stock Exch., 196 F. Supp. 209, 214 (S.D.N.Y. 1961).

5. 196 F. Supp. 209 (S.D.N.Y. 1961).

6. The Silver case was brought by three plaintiffs. They were: Municipal Securities Company, a nonmember over-the-counter securities dealer founded in 1956 and dealing principally in municipal bond transactions; Municipal Securities Company, Inc., a nonmember over-the-counter dealer founded in 1958 for the purpose of trading in unlisted corporate securities; and Harold Silver, owner of Municipal Securities Company and officer and principal shareholder of Municipal Securities Company, Inc.

7. CCH, NYSE Constitution and Rules 1056 (March 1959). Rule 355 of the NYSE's Rules provides:

(a) No member or member organization shall establish or maintain any wire connection, private radio, television or wireless system between his or its office and the office of any non-member, or permit any private radio or television system between his or its offices, without prior consent of the Exchange .... (e) The 
the Exchange denied their request for permanent ticker service, and also directed member firms to disconnect wire service. Despite persistent efforts by plaintiffs to elicit the reason for denial of their requests, the Exchange refused to divulge the charges giving rise to its decision. ${ }^{8}$

Plaintiffs then brought a treble damage action ${ }^{9}$ alleging that disconnection of wire service by order of the Exchange constituted a concerted refusal to deal in violation of section 1 of the Sherman Act. ${ }^{10}$ They also alleged that termination of stock ticker service was an illegal exercise of monopoly power by the Exchange in violation of section 2 of the Sherman Act, ${ }^{11}$ as well as a concerted refusal to deal with plaintiffs in violation of section 1 of that act. The court granted plaintiffs' motion for summary judgment as it applied to discontinuance of wire service, holding that such activity constituted a concerted refusal to deal. It permanently enjoined the Exchange from interfering with plaintiffs' establishment of direct wire connections with member firms and held that treble damages should be awarded to plaintiffs for any injuries to their business. The court denied plaintiffs' motion for summary judgment as it related to the other antitrust allegations, holding that these issues raised

Exchange may require at any time that any means of communication be discontinued.

Rule 356 of the NYSE's Rules provides:

The Exchange may require at any time the discontinuance of any means of communication whatsoever which has a terminus in the office of a member or member organization.

8. Initially the Exchange refused to disclose any reason which prompted it to take the action unless the plaintiffs were willing to release the Exchange, its investigating agencies, and its sources of information from libel or slander liability, or unless it was directed to give its reasons by the court and thereby giving the charges privileged character and insulating the Exchange from a subsequent suit. Neither the court nor the plaintiffs would grant the Exchange's demands. Consequently, only four reasons were ever given by the Exchange for its action-two of which relate essentially to plaintiffs' character. These four reasons were: 1- The Exchange claimed that they had "scurrilous" information about Silver and his wife but labeled it too confidential to disclose. 2- The Exchange charged that the Silvers violated an agreement as to the disposal of shares of U.S. Hoffman Machinery Corporation. 3- It claimed that the application of Municipal, Inc. for approval of private wire connections and stock ticker service failed to list two corporations asked for by the application. 4- The Exchange charged that the security clearance of the Silvers and a corporation with which they were connected had been suspended by the Department of Defense in 1953 under the Industrial Personnel Security Program.

9. 38 Stat. 731 (1914), 15 U.S.C. \$ 15 (1958).

10. 26 Stat. 209 (1890), 15 U.S.C. $\$ 1$ (1958). The part of this section which is pertinent to the discussion of this case states in part that, "Every contract, combination in the form of trust or otherwise, or conspiracy, in restraint of trade or commerce among the several States, or with foreign nations, is declared to be illegal."

11. 26 Stat. 209 (1890), 15 U.S.C. $\$ 2$ (1958). The part of this section which is pertinent to the discussion of this case states that it is illegal to "monopolize, or attempt to monopolize, or combine or conspire with any other person or persons, to monopolize any part of the trade or commerce among the several States, or with foreign nations . ..." 
disputed questions of fact. In response to defendant's argument that it was exempt from antitrust liability because its conduct was prescribed by duties and obligations imposed by the Securities Exchange Act, the court held that neither the act nor its legislative history indicates a congressional intent to grant power to national securities exchanges to regulate nonmember dealers. The court found that the Exchange is not authorized "to exercise any power beyond its own business in listed securities and the ethical conduct of its own membership."12 Moreover, the court rejected another defense argument that, since the Exchange is subject to regulation by the SEC, it is exempt from the antitrust laws at least to the extent that it is acting pursuant to SEC-approved rules requiring the action taken in this case. The court noted that the rules of the Exchange were not affirmatively sanctioned by the SEC.13 It also reasoned that if the defendant's contention were true a mechanism of appeal to the SEC would likely have been provided.14 Having found no "repugnancy" between the regulatory provisions and the antitrust laws, the court concluded that, under the doctrine of Fashion Originators' Guild $v$. Federal Trade Commission, ${ }^{15}$ the defendant's acts constituted a concerted refusal to deal which is a per se violation of the Sherman Act. ${ }^{18}$

The initial inquiry of the district court concerned whether the action of the Exchange was exempt from the Sherman Act. The first issue posed by defendant's argument for exemption was whether an exchange's regulation of over-the-counter security dealers is either a statutory duty imposed by the Securities Exchange Act of 1934, or is a duty emanating from SEC approval of exchange rules regulating over-the-counter dealers.

In order for a national securities exchange to qualify for exemption from antitrust liability, the court must find that Congress intended to vest the exchange with duties which would be frustrated by application of the antitrust laws. Congress, by expressly exempting certain regulatory duties imposed by

12. Silver v. New York Stock Exch., 196 F. Supp. at 221.

13. Ibid.

14. In contrast to the provisions regarding national exchanges, the 1938 amendment provides the procedure for review before the SEC for members of over-the-counter associations who have been disciplined or aggrieved by refusal of membership. 52 Stat. 1070 (1938), 15 U.S.C. $\$ 780-3$ (b) (9) (1958). The district court interpreted the presence of this procedure for review in the 1938 amendment in the absence of any similar procedure in the original act, to indicate that Congress was excluding national exchanges from a supervisory position of over-the-counter dealers. $196 \mathrm{~F}$. Supp. at 220. It seems, however, that an interpretation conferring this same procedure for review in all areas of security regulation would be more in keeping with the spirit of federal regulation. See SEC v. Joiner Corp., 320 U.S. 344, 350, 351 (1943).

15. 312 U.S. 457 (1941). The Fashion Originators' Guild attempted to destroy competition from manufacturers who pirated designs of Guild members by refusing to sell to retailers who sold such copied garments. The Supreme Court, applying the per se rule, held that such an activity constituted illegal monopolistic practice.

16. From the judgment of the district court the New York Stock Exchange appealed to the Second Circuit where the suit is now pending. (Letter from Sidney Dickstein to the Yale Law Journal, October 6, 1961). 
statute, may specify that these duties supersede the antitrust laws. ${ }^{17}$ The Securities Exchange Act of 1934, however, contains no provision insulating exchange activity from antitrust liability. ${ }^{18}$ Therefore, a finding of exemption must rest on an implied intent to exempt based on repugnancy between the antitrust laws and the duties imposed upon the exchange by regulatory legislation. Moreover, the necessary repugnancy must be conspicuous. In Georgia v. Pennsylvania R.R., ${ }^{19}$ the Supreme Court rejected the railroads' claim that as an industry subject to extensive regulation they were exempt from the Sherman Act. The Court noted that "only a clear repugnancy between the old law and the new results in the former giving way and then only pro tanto to the extent of the repugnancy."20

A primary purpose of Congress in enacting the Securities Exchange Act of 1934 was to protect the general investing public. ${ }^{21}$ The act states that:

transactions in securities as commonly conducted upon securities exchanges and over-the-counter markets are affected with a national public interest which makes it necessary to provide for regulation and control of such transactions and of practices and matters related thereto, including transactions by officers, directors, and principal security holders, to require appropriate reports, and to impose requirements necessary to make such regulation and control reasonably complete and effective ... and to insure the maintenance of fair and honest markets in such transaction. ${ }^{22}$

17. The 1938 amendment to the Securities Exchange Act provides an example of where Congress has created a statutory exemption from the antitrust laws. Section $15 \mathrm{~A}(\mathrm{n})$ provides:

If any provision of this section is in conflict with any law of the United States in force on the date this section takes effect, the provision of this section shall prevail.

Thus any over-the-counter association filing under the provisions of this amendment are afforded antitrust exemption. See 2 Loss, Securitres Regulation 1369 (2d ed. 1961).

18. The 1934 act which deals with national stock exchanges has no provision specifically exempting stock exchanges from the application of other statutes. The 1938 amendment to this act, however, provided that, in case of conflict with any other provision of any law, this amendment shall prevail. 52 Stat. 1070 (1938), 15 U.S.C. \& 78o-3n (1958). See note 17 supra. The district court interpreted this exempting provision of the 1938 amendment as excluding the rest of the act. Silver v. New York Stock Exch., 196 F. Supp. 209, 220 (S.D.N.Y. 1961). It seems, however, that the court could have as easily interpreted this exempting clause either to indicate full exemption for the entire act or that Congress had already considered the 1934 act to be exempt when it came into conflict with other laws.

19. Georgia v. Pennsylvania R.R., 324 U.S. 439 (1945).

20. Id. at 456-57.

21. Baird v. Franklin, 141 F.2d 238, 244 (2d Cir. 1944).

22. 48 Stat. 881 (1934), 15 U.S.C. \& 78b (1958). There are some thirty-six other sections which refer to this same objective. They are: $\$ \$ 5,6$ (a) (2), 7 (d), 9 (a) (6), 9 (b), 9 (c), 10(a), 10(b), 11(a), 11(b), 11(c), 12(b) (1), 12(b) (2), 12(d), 12(e), 12(f), 13 (a), 14(a), 14(b), 15(b), 15(c) (3), 15(d), 15A(a)(1), 15A(b) (3), 15A(b) (4), $15 \mathrm{~A}(\mathrm{~b})(7), 15 \mathrm{~A}(\mathrm{c}), 15 \mathrm{~A}(\mathrm{~h})(\mathrm{a}), 15 \mathrm{~A}(\mathrm{j}), 15 \mathrm{~A}(\mathrm{k}), 15 \mathrm{~A}(\mathrm{l}), 17$ (a), 19(a), 19(b), 24, 30, $78 \mathrm{e}, 78 \mathrm{f}$ (a) (2), $78 \mathrm{~g}$ (d), $78 \mathrm{i}$ (a) (6), $78 \mathrm{i}$ (b) \& (c), 78j (a)\&(b), 78k (a)-(c), 78l(b) (1) \& (2), 781 (d)-(f), 78m(a),78n (a,b), 780 (b), 78o (c) (3), (d), 78o-3 (a) (1), 780 (b) (3), (4), (7), (c),78o(h) (2), 78o(j-l),78q(a), 78s (a) \&(b),78x,78dd. 
Senate reports prior to passage of the act indicate that Congress recognized that, in the absence of regulatory legislation, the exchanges had found it impracticable to control nonmember dealers. ${ }^{23}$ This difficulty was cited to indicate the need for a regulatory commission. While the act empowers the SEC to regulate over-the-counter dealers, ${ }^{24}$ it cannot, however, be read to abrogate the regulatory functions exercised by the exchanges. Indeed, in the 1938 amendment relating specifically to regulation of over-the-counter dealers by dealers' associations, ${ }^{25}$ Congress again declined to specify that the regulatory powers of the SEC or any organization registering under the amendment are exclusive. Since neither the 1934 act nor the 1938 amendment evinces congressional intent to abrogate the authority of a national securities exchange to regulate nonmember dealers, it is arguable that the act simply provides additional regulation designed in part to control those over-thecounter transactions that the exchanges cannot effectively supervise.

Among the conditions imposed upon an exchange by the act as a prerequisite to registration with the SEC is the adoption of rules and practices that are "just and adequate to insure fair dealing and to protect investors." 20 Under this broad statutory mandate, it would seem to follow that failure by an exchange to enforce rules authorizing discipline of nonmember dealers found to be conducting illegal or improper transactions involving members would constitute a violation of law subjecting the exchange's registration to SEC revocation. ${ }^{27}$ Moreover, it should be presumed that the SEC, entrusted to effectuate the objectives of the act, approves only those rules and constitutions of registering exchanges that are consistent with the regulatory scheme envisioned by Congress. There is nothing in the act or legislative history that prohibits the SEC from using a national exchange as a subordinate regulatory body, and the acquiescence of the SEC to exchange rules designed to control over-the-counter dealers associated with member firms suggests SEC incorporation of these rules into its own regulatory scheme. Moreover, since a national exchange is an institution sensitive to information regarding trading

23. S. REp. No. 792, 73 Cong., 2d Sess. 45 (1934). This report resulted from the hearings prior to the enactment of the Securities Exchange Act of 1934. In noting the inability of national exchanges to cope with all of the problems raised by over-the-counter dealers, the report stated in part:

[t]he control exercised by stock exchange authorities is admittedly limited to their own members, and they are unable to cope with those practices of nonmembers which they deplore but cannot prevent.

24. 48 Stat. 895 (1934), 15 U.S.C. $\$ 78 o$ (1958).

25. 52 Stat. 1070 (1938), 15 U.S.C. $\$ 780-3$ (1958).

26. 48 Stat. 885 (1934), 15 U.S.C. \& 78f(d) (1958).

27. The Securities Exchange Act provides that the Commission is authorized to withdraw the registration of a national securities exchange if it finds that ". . . such exchange has violated any provision of this chapter or of the rules and regulations thereunder or has failed to enforce, so far as is within its power, compliance therewith by a member or by an issuer of a security registered thereon." 48 Stat. 898 (1934), 15 U.S.C. $\$ 78$ s(a) (1) (1958). (Emphasis added). 
misconduct in securities, it is probable that the SEC favors the exchange's involvement in over-the-counter trading regulation in order that this source of valuable information to the SEC is preserved. Therefore, the court in Silver might have interpreted the Securities Exchange Act as imposing a duty on the Exchange to enforce its rules against the plaintiffs; antitrust liability could then have been deemed repugnant to this statutory duty.

A finding of clear repugnancy between the antitrust laws and the Securities Exchange Act, however, would not have been determinative of the exemption issue in this case. The court would also have to find that the very acts giving rise to the alleged antitrust violation derived from the statutory duty. Thus if the court found that the disciplinary action taken against plaintiffs was unreasonable, it could have argued that since the act imposes no duty to discipline beyond the bounds of reasonableness, such "ultra vires" activity was not exempt from the application of the antitrust laws. The Securities Exchange Act of 1934 requires that the rules of a registered exchange be "just." 2 S Moreover, the SEC is required by the act to compel an exchange to adopt rules which provide for the "fair administration of such exchange." 29 The preoccupation of Congress in 1934 with the need for broad legislation to curtail trading abuses prevalent at that time precluded it from fashioning procedural rules which would give content to the requirement of "just" rules providing for "fair administration." But, when Congress addressed itself for the first time to the task of drafting detailed securities legislation, the 1938 amendment relating to over-the-counter securities required that dealers be afforded a hearing before disciplinary action is taken by dealers' associations. ${ }^{30}$ Arguably, the 1938 amendment casts light upon the general requirement in the 1934 act that disciplinary rules be just and conducive to the fair administration of the exchange. If the hearings provision of the 1938 amendment is considered indicative of congressional intent of 1934 act provisions relating to exchange rules, a hearing requirement should be read into the disciplinary rules of the Exchange. Hence, the statutory duty of granting a hearing would be placed upon the Exchange, and by implication would be incorporated into its disciplinary rules. In such a case, a court might construe a disciplinary rule approved by the SEC to contain a hearing requirement despite the absence of explicit mention in the Exchange's rule. By adopting this reasoning, the court in Silver might have concluded that, whether or not a repugnancy existed between the antitrust laws and the disciplinary rule of the exchange approved by the SEC, the Exchange did not act pursuant to such rule because it denied a hearing implicit in the rule.

The court in Silver might have found still another reason for rendering its inquiry more limited than the one actually adopted. To the extent that the charges brought by the Exchange related to bare allegations of plaintiffs' bad

28. 48 Stat. 885 (1934), 15 U.S.C. $\$ 78 f(d)$ (1958).

29. 48 Stat. 898 (1934), 15 U.S.C. $\$ 78$ s(b) (1958).

30. 52 Stat. 1070 (1938), 15 U.S.C. § 780 (b) (9) (1958). 
character, ${ }^{31}$ the disciplinary action taken may well have fallen outside the proper regulatory scope of the Exchange. One charge upon which the Exchange acted was that plaintiffs had been denied security clearance for a brief period by the Department of Defense. ${ }^{32}$ But neither the Securities Exchange Act of 1934 nor the SEC imposes a duty upon an exchange to apply approved disciplinary rules in cases where the questionable character of a party is not linked to misconduct, or the likelihood of misconduct, in securities trading. The act suggests that Congress intended to create a regulatory scheme designed only to prevent and remedy trading abuses, while the Exchange in Silver seems to have acted partially in response to political considerations, ${ }^{33}$ rather than to a need to prevent or correct any trading misconduct by the plaintiffs. Therefore, to the extent that the disciplinary action was taken because of plaintiffs' security status, it may be argued that such action was not sanctioned by the 1934 act and could not be considered by the court as a basis for exempting the Exchange from the antitrust laws.

Having found that the Exchange was not exempt from the application of the antitrust laws, the court had little difficulty holding that the Exchange's order to its members to discontinue wire service constituted a concerted refusal to deal ${ }^{34}$ with plaintiffs. Concerted refusals to deal, ${ }^{35}$ along with price fixing, ${ }^{36}$ division of markets, ${ }^{37}$ and tying arrangements, ${ }^{38}$ have generally

31. See note 8 supra.

32. Silver v. New York Stock Exch., 196 F. Supp. 209, 226 (S.D.N.Y. 1961).

33. Ibid.

34. Id. at 223.

35. Concerted refusals to deal are combinations formed to coerce third parties; they have been held per se illegal regardless of their purpose. See, e.g., Eastern States Retail Lumber Dealers Ass'n v. United States, 234 U.S. 600 (1914) ; United States v. Frankfort Distilleries, Inc., 324 U.S. 293 (1945). Cf. Kiefer-Stewart Co. v. Joseph E. Seagram \& Sons, Inc., 340 U.S. 211 (1951) ; Associated Press v. United States, 326 U.S. 1 (1945). See also dicta in Times-Picayune Publishing Co. v. United States, 345 U.S. 594, 625 (1953) ; United States v. Columbia Steel Co., 334 U.S. 495, 522 (1948). But see Barber, Refusals to Deal Under the Federal Anti-Trust Lazes, 103 U. PA. L. REv. 847, 879 (1955).

36. Price fixing has been described as the most important of the per se offenses. Arr'y Gen. Nat'l Comm. Antitrust Rep. 12 (1955). In United States v. Socony-Vacuum Oil Co., 310 U.S. 150, 223 (1940), the Court held that "a combination formed for the purpose and with the effect of raising, depressing, fixing, pegging, or stabilizing the price of a commodity in interstate or foreign commerce is illegal per se." See generally 1 TRADE REG. REP. If 4020 (1961).

37. Market division agreements among competitors are held to be unreasonable because of their character and necessary effect on competition. "They are agreements with no purpose other than the elimination of competition ...." Atr'y Gen. NAT'L CoMrr. Antrtrust Rep. 26 (1955). Thus in Addyston Pipe \& Steel Co. v. United States, 175 U.S. 211 (1899), the Supreme Court held an agreement between competitors which tended to eliminate competition illegal because prices were fixed from a division of the market among manufacturer which supplied about two-thirds of the cast-iron pipe market. See also Timken Roller Bearing Co. v. United States, 341 U.S. 593 (1951), for a more recent condemnation of market allocation between competitors.

38. Tying arrangements which condition the sale or lease of one product on use of another are another type of conduct which has been placed in the per se category. See, $\varepsilon . g$., 
been considered illegal per se under the antitrust laws, thereby precluding any further consideration of reasonableness. ${ }^{30}$ However, an examination of what courts have done when confronted with refusal to deal cases reveals that they usually do consider the reasonableness of the restraint in determining whether the practice should be upheld. If the court is convinced that the defendant's activity bears little relation to a socially desirable goal, the label "concerted refusal to deal" is attached and a per se violation exists. ${ }^{40}$ If, however, the court concludes that the questioned activity is reasonable, it will often judiciously avoid use of a conclusionary term and will find no violation of the antitrust laws. ${ }^{41}$ Chicago Board of Trade $v$. United States ${ }^{42}$ is illustrative. The Department of Justice attacked a rule of the Board of Trade that members were prohibited from purchasing or offering to purchase grain during the period between the close of the call and the opening of the next business day at a price other than the closing bid at the call. The Government alleged that this "call" rule amounted to price-fixing and constituted a per se violation of the Sherman Act. Without once referring to the call rule as a price-fixing agreement, the Supreme Court reversed the district court decision that sustained the Government's contention, holding that the call rule consti-

International Salt Co. v. United States, 332 U.S. 392 (1947) ; Northern Pac. Ry. v. United States, 356 U.S. 1, 11 (1958). But see Note, 70 YaLE L.J. 804 (1961).

39. The doctrine of per se illegality has been used by the courts to preclude the operation of the rule of reason to practices falling into the categories of price fixing, division of markets, group boycotts, and trying arrangements. Thus, if the prescribed conduct is labeled a per se violation, "there is no inquiry into factual circumstances and economic data to determine whether an agreement or practice constitutes a reasonable or an unreasonable restraint of trade. Agreements or practices falling into this category are presumed to be unreasonable." 1 Trade Reg. Rer. $\int 500$ (1961). See generally Note, 58 YALE L.J. 1121, 1136-40 (1949); Kirkpatrick, Commercial Boycotts as Per Se Violations of the Sherman Act, 10 Geo. WASH. L. REv. 302 (1942) (cases cited therein).

40. Commentators on the per se rule have reached similar conclusions but have described the court's action in different terms. For example, Barber, supra note 35, at 872, separated concerted refusals to deal into two groups. Those designed to coerce the conduct of third parties or to secure their removal from competition were placed within the per se category while those without this intent were not so labeled. He concluded that the real issue in these cases "is not the existence or nonexistence of concerted refusal to deal, but rather whether the purpose and effect of the operation of the contract, association, exchange or joint sales agency was such as unreasonably to exclude outsiders from participation in the trade in question." Id. at 877.

41. United States v. Morgan, 118 F. Supp. 621, 689 (S.D.N.Y. 1953), is one example of a court testing the reasonableness of the action in what would otherwise be a concerted refusal to deal. See also Young v. Motion Picture Ass'n, 5 Trade Reg. Rep. If 70139 (D.D.C. 1961) ; Molinas v. National Basketball Ass'n, 190 F. Supp. 241 (S.D.N.Y. 1961).

42. 246 U.S. 231 (1918) ; Neale, The Antitrust Laws of the U.S.A. (1960) states in his commentary on the Chicago Board of Trade case that although market sharing is illegal per se under section 1 of the Sherman Act "it is, of course, possible that a set of facts could be found or invented, such that it could be brought under the head of marketsharing but not regarded as showing a significant restraint of trade, just as in the Chicago Board of Trade case a set of facts which could be called price-fixing was found insignificant. In this sense the Rule of Reason would come into play." 
tuted a reasonable regulation designed to prevent exploitation by traders who acquired information after closing that would be available to all traders on the Board the following day. The Court held that:

The true test of legality is whether the restraint imposed is such as merely regulates and perhaps thereby promotes competition or whether it is such as may suppress or even destroy competition .... The District Court erred, therefore, in striking from the answer allegations concerning the history and purpose of the Call rule and in later excluding evidence on that subject. ${ }^{43}$

Even if the court in Silver followed the implications of Chicago Board of Trade, it still could have found the Exchange's conduct unreasonable. First, the Exchange was unable to prove the truth of charges underlying its order to disconnect wire services; indeed, the court found such charges untenable.14 Second, even if the Exchange had satisfied its burden of proving the truth of the charges against plaintiffs, the denial of a hearing to plaintiffs required it to take regulatory action on the basis of a one-sided and incomplete knowledge of the facts. And, even assuming that the Securities Exchange Act of 1934 authorizes the Exchange to exercise regulatory power in situations of this type, it is unreasonable for the Exchange to exercise disciplinary power in the absence of all the evidence relating to whether plaintiff' dealings conflicted with the objectives of securities legislation. Therefore, since the Exchange precluded itself from a full understanding of the facts, the restraint of trade in which it engaged was unreasonable and violative of the Sherman Act.

Thus far, it has been assumed that the courts are appropriate institutions for trying cases similar to Silver, and that antitrust liability is a satisfactory remedy. The repercussions of this decision upon securities regulation may, however, be undesirable. If the Silver case is read broadly to prohibit a national securities exchange from ever regulating nonmember dealers, it would tend indirectly to limit the avenues through which the SEC could regulate over-the-counter transactions. Since the securities legislation does not specify any limitation on the means available to the SEC to regulate over-thecounter transactions, the Silver case, by precluding the SEC from utilizing the Exchange for this purpose, could unduly restrict the SEC's regulatory powers. Moreover, even if the Silver decision is read narrowly to hold only that the specific action taken against the plaintiffs was not a proper exercise of a regulatory duty imposed upon the Exchange, the holding may still be undesirable. Since an antitrust violation would render it liable for substantial treble damages, ${ }^{45}$ the Exchange might be deterred from fully participating in the area of over-the-counter regulation. Even if the Exchange rectified its unfair disciplinary procedure by providing a hearing, its decision to discipline any given nonmember might still be challenged in a subsequent treble damage action brought by the nonmember.

43. Chicago Bd. of Trade v. United States, 246 U.S. 231, 238-39 (1918).

44. Silver v. New York Stock Exch., 196 F. Supp, at 227.

45. 38 Stat. 731 (1914), 15 U.S.C. \& 15 (1958). 
A requirement that the Exchange conduct a disciplinary hearing may be found if the Exchange's regulation of securities practices is labeled a governmental function subject to certain basic constitutional limitations. ${ }^{46}$ While the guarantee of due process is a limitation only upon governmental action ${ }^{47}$ and an exchange is usually characterized as an unincorporated private association, ${ }^{48}$ the trend of judicial decisions has been toward enlarging the zone of governmental activity by rendering private lawmaking groups subject to due process requirements. ${ }^{49}$ The implications of calling an exchange a governmental agency, however, may be much broader than a decision prescribing a hearing would require. It is difficult to see where the courts would draw

46. In re Central R.R., 136 F.2d 633, 639 (3d cir. 1943). The court in this railroad reorganization proceeding noted that

The right to notice and a hearing is one of ancient origin and by the due process clauses of the 5th and 14th amendments has been safeguarded to all against deprivation by the federal government and the states respectively.

For the application of the due process clause to administrative proceedings of a quasi-judicial character, see Morgan v. United States, 304 U.S. 1 (1938).

47. The fifth amendment is a limitation only upon the powers of the government, and is not directed against the action of individuals. See Corrigan v. Buckley, 271 U.S. 323, 330 (1926).

The fourteenth amendment has also been held to apply only to the action of state governments and not against the action of private groups or individuals. Civil Rights Cases, 109 U.S. 3 (1883).

48. Silver v. New York Stock Exch., 196 F. Supp. at 210.

49. Beginning with the creation of the American federal system in 1789, and especially following the enactment of the fourteenth amendment in 1868, more and more governmental activity has been made subject to due process limitation. Miller, The Constitutional Law of the "Security State," 10 Sran. L. Rev. 620, 664 (1958), states that the democratic process has always had the problem of curbing the excesses of private groups. He asserts as his basic premise that "governing power, wherever located, should be subjected to the fundamental constitutional limitation of due process of law." Id. at 663.

The application of the due process clause to curb these "excesses of private groups" has been employed by the Supreme Court in several recent cases. In Shelley v. Kraemer, 334 U.S. 1 (1948), the Court held that the judicial enforcement by state courts of a restrictive covenant between private individuals which discriminated against Negroes made the state court a guilty partner in the racial discrimination and therefore violated the fourteenth amendment. In the area of primary election, the Court in Smith v. Allwright, 321 U.S. 649 (1944), held that the Texas Democratic Party, a private voluntary association which had excluded Negroes, was subject to the fourteenth amendment's due process clause because its recognition and use by the state to aid in the selection of candidates made its conduct governmental action. Still again in Marsh v. Alabama, 326 U.S. 501 (1946), the Supreme Court held that action by a town owned by a private corporation was limited by the due process clause because of its essential similarity to a publicly controlled town.

Friedmann, Corporate Powcr, Government by Private Grotess, and the Law, 57 Colus. L. Rev. 155, 176 (1957), has suggested that power wherever located should be subject to the fundamental constitutional limitations of due process of law. He states:

The corporate organizations of business and labor have long ceased to be private phenomena. That they have a direct and decisive impact on the social, economic, and political life of the nation is no longer a matter of argument. It is an undeniable fact of daily experience. The challenge to the contemporary lawyer is to translate the 
the line in holding persons affected by such groups entitled to the guarantees afforded by the Constitution. Therefore, while courts may be able to impose an affirmative duty upon an exchange to hold hearings, even in the absence of legislation creating such a duty, the problems inherent in both the due process and the antitrust approaches speak strongly for an alternative means of insuring fairness in an exchange's disciplinary procedure.

The deficiencies inherent in the antitrust and due process approaches can be avoided by adoption of a procedure similar to that sanctioned by Congress in the 1938 amendment to the Securities Exchange Act. ${ }^{50}$ This amendment required that over-the-counter dealers' associations provide hearings in all disciplinary proceedings ${ }^{51}$ and that the SEC decide appeals from the association's decision. ${ }^{52}$ Thus, Congress seems to have felt that a disciplinary procedure consisting of a hearing and a right to appeal to the SEC for review was most promotive of the goals of securities regulation.

The Securities Exchange Act of 1934 may be read to authorize the SEC to promulgate rules requiring a hearing whenever an exchange attempts to discipline over-the-counter dealers. This act directs the SEC to make "such rules and regulations as may be necessary for the execution of the functions vested in [it] by this chapter." 53 Since one of the SEC's functions is to insure the fair administration of an exchange's activities, ${ }^{54}$ promulgation of a hearings rule to be complied with by the exchanges would be proper. And, if an exchange failed to adhere to the SEC rule by denying a hearing to over-thecounter dealers in disciplinary proceedings, the SEC is authorized by statute to suspend or revoke the exchange's registration. ${ }^{65}$ Moreover, if a provision is included in the SEC rule allowing for an appeal to the SEC by nonmember dealers who have been denied a hearing, still another objective of the $193 \mathrm{~S}$ amendment can be incorporated into the field of exchange regulation. ${ }^{66} \mathrm{By}$ providing in the 1938 amendment for an appeals mechanism to the SEC from decisions of a dealers' association, Congress seems to have intended that court involvement be postponed until disputes of this nature have been considered by the SEC. Providing an appeals mechanism to the SEC for over-the-counter dealers denied a hearing in exchange disciplinary proceedings would, under the

social transformation of these organizations from private associations to public organisms into legal terms.

See generally Hale, Freedom Through Law (1952) ; Pekelis, Law and Social Action (1950); and Wirtz, Government by Private Groutps, 13 LA. L. Rev. 440 (1953).

50. The 1938 amendment to the Securities Exchange Act of 1934 providing, among other things, a procedure for review and appeal in disciplinary actions for over-the-counter associations registering under the amendment, does not apply to exchanges. See note 14 supra and accompanying text.

51. 52 Stat. 1070 (1938), 15 U.S.C. $\$ 780-3$ (b) (9) (1958).

52. 52 Stat. 1070 (1938), 15 U.S.C. $\$ 780-3(\mathrm{~h})(1958)$.

53. 48 Stat. 901 (1934), 15 U.S.C. \& 78w (a) (1958).

54. 48 Stat. 898 (1934), 15 U.S.C. $\$ 78 \mathrm{~s}$ (b) (1958).

55. 48 Stat. 898 (1934), 15 U.S.C. $\$ 78$ s (a) (1) (1958).

56. See note 50 supra. 
doctrine of primary jurisdiction, preclude the type of suit brought in the Silver case until the SEC has had an opportunity to review the exchange's conduct. ${ }^{57}$ The SEC would be free, therefore, to weigh the exchange's actions in the light of regulatory policies, and would not encounter the problems that face a court when the denial of a hearing is couched in terms of an antitrust violation or an abridgment of due process.

57. If the court adopted a solution employing the doctrine of primary jurisdiction, situations like that in Silver would gain the advantage of administrative expertise while at the same time avoid the awkwardness of forcing the SEC to file amicus curiae briefs with federal courts to express opinions on pending suits. See BNA, ANTITRUST Trade REg. REP., Dec. 5, 1961, p. 11. For general treatment of primary jurisdiction and antitrust problems, see 3 Davis, Administrative Law Treatise $\llbracket$ 19.05, at 23 (1958). 